\title{
Sistem Pakar Mendiagnosa Penyakit Tropik Infeksi Dengan Menggunakan Metode Certainty Factor (CF)
}

\author{
Ira Tasya Mawaddah ${ }^{1}$, Sulindawaty ${ }^{2}$ \\ 1,2 Jl. Iskandar Muda No.1, STMIK Pelita Nusantara Medan, Indonesia

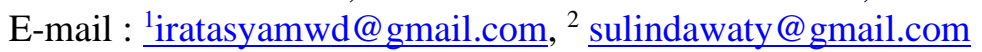

\begin{abstract}
The impact of computer technology has played a major role in changing aspects of human life, especially in the health sector where in the midst of an epidemic that hit a system that is able to reduce the impact of the crowd is needed. One of them is a system for diagnosing disease, and the disease to be studied is a type of infectious disease and a disease that is increasing in the midst of an epidemic, namely infectious tropical diseases or diseases that develop in a tropical climate. The purpose of this study is to build a web-based expert system application that is able to diagnose infectious tropical diseases using the certainty factor (CF) method, and development using the waterfall model. Tests are carried out with blackbox tests and validity tests, on blackbox tests the system runs as expected and on the validity test the system is declared valid to be used. In the user test, the calculation obtained using the CF method is $97.65 \%$ certainty level. The research concludes that the system is able to provide a confidence value and can diagnose the type of infectious tropical disease based on the symptoms selected by the user. Because the system still has limitations, it is hoped that the system will be developed using other methods so that it is more useful for users.
\end{abstract}

Keywords- Tropical Diseases, Expert System, Certainty Factor

\begin{abstract}
Abstrak-Dampak teknologi komputer telah berperan besar dalam perubahan aspek kehidupan manusia, khususnya di bidang kesehatan dimana ditengah wabah yang melanda diperlukan sebuah sistem yang mampu mengurangi dampak kerumunan. Salah satunya sistem mendiagnosa penyakit, dan penyakit yang akan diteliti merupakan jenis penyakit menular serta penyakit yang mengalami peningkatan ditengah wabah yaitu penyakit tropik infeksi atau penyakit yang berkembang diiklim tropis. Tujuan penelitian ini adalah membangun sebuah aplikasi sistem pakar berbasis web yang mampu mendiagnosa penyakit tropik infeksi menggunakan metode certainty factor (CF), dan pengembangan menggunakan model waterfall. Pengujian dilakukan dengan uji blackbox serta uji validitas, pada uji blackbox sistem berjalan dengan yang diharapkan dan pada uji validitas sistem dinyatakan valid untuk digunakan. Pada uji pengguna mendapat perolehan perhitungan menggunakan metode CF sebesar 97,65\% tingkat kepastian. Penelitian menghasilkan kesimpulan bahwa sistem mampu memberikan nilai kepercayaan dan dapat mendiagnosis jenis penyakit tropik infeksi berdasarkan gejala yang dipilih user. Karena sistem masih memiliki keterbatasan, diharapkan adanya pengembangan sistem dengan metode lain sehingga lebih bermanfaat bagi pengguna.
\end{abstract}

Kata kunci- Tropik Infeksi, Sistem Pakar, Certainty Factor

\section{PENDAHULUAN}

Perkembangan teknologi komputer sangat berpengaruh bagi segala aspek kehidupan manusia, diera ini teknologi informasi mampu mempermudah segala pekerjaan manusia dalam menjalani kesehariannya. Salah satu aspek yang sangat dibutuhkan pada masa kini adalah bidang kesehatan, teknologi sangat membantu dalam pelayanan kesehatan dengan mudah dan cepat. Di tengah pandemi virus Covid-19 yang tengah mewabah diseluruh dunia teknologi berperan penting dalam bidang kesehatan, oleh karena itu dengan adanya teknologi mampu menjadi jembatan antar pasien dengan tenaga kesehatan. Sebuah sistem yang dibangun sebagai penghubung, sistem yang mampu mendiagnosa suatu penyakit tanpa perlu datang bertemu seorang ahli atau tanpa perlu adanya kunjungan langsung yang dapat mengurangi dampak dari penyebaran virus Covid-19[9],[10].

Penyakit tropik infeksi merupakan penyakit yang sering terjadi diwilayah dengan iklim tropis, Indonesia menjadi salah satu negara beriklim tropis dikarenakan letak Indonesia yang berada digaris khatulistiwa menjadi faktor utama penyakit ini muncul. Faktor iklim tersebut mendukung pengembangbiakan virus, bakteri, juga jamur yang mampu menyebabkan munculnya penyakit dan infeksi yang disebut penyakit tropis. Penyakit tropis merupakan kondisi terjadi semata-mata atau terutama didaerah tropis. Dalam praktiknya, istilah yang sering digunakan untuk merujuk pada penyakit menular yang berkembang dalam kondisi panas dan lembab. Penyakit tropik-infeksi ditangani serta didiagnosa oleh dokter spesialis penyakit dalam[1],[2].

Di Indonesia kasus penanganan penyakit tropikinfeksi mengalami peningkatan ditengah pandemi ini dikarenakan pemerintah berfokus pada wabah yang tengah menyerang dunia dan ditambah dengan iklim yang tengah terjadi di Indonesia dimana curah hujan yang tidak menentu menjadi faktor utama pengembangbiakan virus, bakteri dan kuman. Adapun penyakit yang berpotensi mengalami peningkatan adalah Demam Berdarah (DBD), Tuberkulosis (TB Paru), gangguan pada pencernaan, 
gangguan pada pernafasan, serta gangguan pada kulit. Untuk di Indonesia sendiri kasus yang banyak terjadi adalah demam tinggi serta gangguan pada pernafasan disebabkan suhu lingkungan yang berubah-ubah. Sehingga tercapai suatu kesimpulan untuk membangun sebuah sistem pakar dapat menggunakan beberapa metode namun untuk diagnosa penyakit tropik infeksi yaitu dengan metode Certainty Factor[3],[4].

Tujuannya yaitu dapat mengetahui penyakit tropik infeksi yang dialami pasien dengan mudah tanpa harus melakukan diagnosa secara manual dan dapat membangun aplikasi sistem pakar pada penyakit tropik infeksi dengan metode Certainty Factor[5],[8].

Manfaatmya yaitu menambah ilmu dan wawasan yang di dapat saat melakukan penelitian langsung, serta untuk menambah pengetahuan penulis tentang penelitian selanjutnya tentang ilmu yang ditekuni bukan hanya secara teoritis melainkan langsung kepada penerapan di lapangan, sebagai bahan referensi yang akan melakukan penelitian sistem pakar dengan Metode Certainty Factor dan dapat mempermudah dalam mengidentifikasi/ mendapatkan solusi terkait permasalahan pada pasien[6],[7].

\section{METODE PENELITIAN}

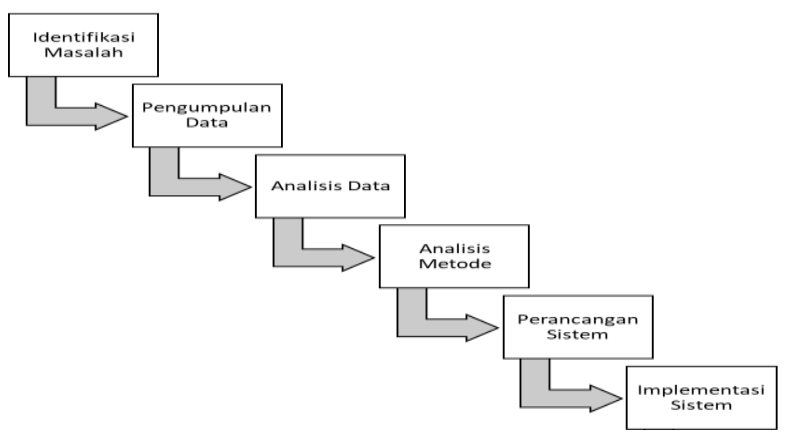

Gambar 1. Kerangka Kerja Penelitian

Pada tahapan ini akan menguraikan kerangka kerja penelitian atau tahapan - tahapan yang dilakukan dalam melaksanakan penelitian, tahapan penelitian ini dilakukan agar dapat menyelesaikan masalah yang akan dibahas, hal ini dilakukan dengan tujuan untuk mengumpulkan informasi - informasi berkaitan dengan masalah yang diteliti:

\section{Identifikasi Masalah}

Masalah penelitian akan menentukan kualitas dari penelitian, bahkan juga menentukan apakah sebuah kegiatan bisa disebut penelitian atau tidak. Masalah yang dihadapi tidak adanya sistem untuk mendiagnosis penyakit tropik infeksi serta keterbatasan informasi mengenai gejala-gejala dan jenis penyakit tropik infeksi pada Klinik Kesuma Bangsa. Penulis merancang sistem pakar diagnosa penyakit tropik infeksi dengan metode

2. Pengumpulan Data

Pada tahap ini dilakukan proses pengumpulan data dilakukan dengan metode wawancara untuk melakukan pengamatan dan analisa terhadap pengetahuan tentang jenis penyakit tropik infeksi sehingga mendapatkan data dan informasi yang dibutuhkan seperti data fisik gejalagejala dann solusi dari penyakit tropik infeksi yang dialami oleh manusia. Data-data tersebut didapatkan dari pakar yaitu dr. Heri Gunawan,Sp. PD sebagai dokter spesialis penyakit dalam sekaligus penanggung jawab dan dr. Aldrian Saforta selaku dokter umum yang membantu dalam tahap awal menangani kasus pasien terinfeksi penyakit tropik di Klinik Kesuma Bangsa.

Teknik pengumpulan data yang dipergunakan dalam penelitian ini adalah:

a. Wawancara

Wawancara dalam penelitian ini dilakukan dengan mengajukan pertanyaan-pertanyaan terstruktur. Wawancara tersebut dilakukan pada dr. Heri Gunawan, Sp. PD sebagai pakar dalam penelitian tersebut.

b. Dokumentasi

Dokumentasi adalah salah satu cara pengumpulan data dengan mengalisis atau melihat dokumendokumen yang dibuat oleh pakar. Dokumentasi dilakukan dengan mengumpulkan data dari

dokumen yang sudah ada, sehingga peneliti dapat memperoleh catatan, foto-foto dan sebagainya.

c. Studi Pustaka

Studi pustaka adalah metode pengumpulan informasi dan data dengan melakukan kegiatan kepustakaan melalui jurnal, buku-buku, penelitian terdahulu dan lain sebagainya yang berkaitan dengan penelitian yang sedang dilakukan.

3. Analisis Data

Pada tahap ini dilakukan analisis masalah dari data yang diperoleh. Dengan demikian, diharapkan peneliti dapat menemukan permasalahan yang terjadi di tempat riset dilakukan tentang gejala-gejala atau jenis-jenis penyakit tropik infeksi dan penatalaksanaan awal atau penanganan awal dari penyakit tropik infeksi sehingga peneliti dapat mencari solusi dari permasalah tersebut.

4. Analisis Metode

Pada tahap ini dilakukan analisis metode yaitu menggunakan metode certainty factor. Dengan demikian, diharapkan peneliti dapat menemukan solusi permasalahan dengan perhitungan sesuai dengan rumus beserta nilai yang diperoleh dari pakar.

\section{Perancangan Sistem}

Tahap ini membahas tentang perancangan dari model sistem dengan merancang aplikasi sistem pakar diagnosa penyakit tropik infeksi menggunakan metode certainty factor. Pada perancangan sistem menggunakan diagram UML bertujuan untuk menggambarkan atau memodelkan aplikasi diagram yang digunakan yaitu Use Case Diagram, Activity Diagram, Class Diagram, Sequence Diagram. 
Tahap ini juga membahas tentang rancangan basis data yang digunakan, perancangan basis data bertujuan untuk mengelompokkan data-data yang berhubungan. Dan pada tahap perancangan antar muka pada aplikasi sistem pakar akn dibuat bentuk interface serta menumenu yang terdapat pada program nanti.

6. Implementasi Sistem

Implementasi yang akan dibangun menggunakan bahasa pemrograman PHP dengan menggunakan MySQL sebagai basis datanya. Setelah melakukan implementasi maka penulis melakukan pengujian yang bertujuan untuk menjaamin sistem yan diabuat sesui dengan hasil analisis dan perancangan serta menghasilkan satu kesimpulan apakah sistem tersebut sesuai dengan yang diharapkan. Jika terdapat kesalahan atau error, maka tahap inilah dilakukan perbaikan atau modifikasi sistem.

\section{HASIL DAN PEMBAHASAN}

Tabel 1. Jenis - Jenis Penyakit Tropik Infeksi

\begin{tabular}{cl}
\hline $\begin{array}{c}\text { Kode } \\
\text { Penyakit }\end{array}$ & \multicolumn{1}{c}{ Nama Penyakit } \\
\hline P1 & Demam Berdarah Dengue (DBD) \\
\hline P2 & Demam Tifoid \\
\hline P3 & Hepatitis \\
\hline P4 & Tuberkulosis (TBC) \\
\hline P5 & Filariasis (Kaki Gajah) \\
\hline P6 & Varicella (varisela) \\
\hline P7 & Difteri \\
\hline
\end{tabular}

Tabel 2. Gejala - Gejala Penyakit Tropik Infeksi

\begin{tabular}{cl}
\hline $\begin{array}{c}\text { Kode } \\
\text { Gejala }\end{array}$ & \multicolumn{1}{c}{ Gejala } \\
\hline G01 & Demam \\
\hline G02 & Nyeri Kepala \\
\hline G03 & Nyeri Bagian Mata \\
\hline G04 & Nyeri Otot \\
\hline G05 & Nyeri Sendi \\
\hline G06 & Ruam (Bintik) Kemerahan \\
\hline G07 & Pendarahan Spontan dari Hidung dan Gusi \\
\hline G08 & Penurunan tekanan darah \\
\hline G09 & Peningkatan kecepatan denyut nadi \\
\hline G10 & Jumlah volume urine menurun \\
\hline G11 & Mual dan Muntah \\
\hline G12 & Gangguan BAB (mencret atau konstipasi) \\
\hline G13 & Nyeri Perut \\
\hline G14 & BAB berdarah \\
\hline
\end{tabular}

\begin{tabular}{|c|c|}
\hline $\begin{array}{c}\text { Kode } \\
\text { Gejala }\end{array}$ & Gejala \\
\hline G15 & Nafsu makan menurun \\
\hline G16 & Kejang \\
\hline G17 & Penurunan kesadaran \\
\hline G18 & Mata dan kulit berwarna kuning \\
\hline G19 & Lemah, letih dan lesu \\
\hline G20 & Warna urine seperti warna teh \\
\hline G21 & Tinja seperti dempul \\
\hline G22 & Batuk \\
\hline $\mathrm{G} 23$ & Sesak Nafas \\
\hline G24 & Nyeri dada \\
\hline G25 & Batuk Berdarah \\
\hline G26 & Penurunan Berat Badan \\
\hline G27 & $\begin{array}{l}\text { Berkeringat malam tanpa melakukan aktivitas } \\
\text { berat }\end{array}$ \\
\hline G28 & $\begin{array}{l}\text { Pembengkakan di bagian kelenjar getah } \\
\text { bening }\end{array}$ \\
\hline G29 & Nyeri dan merah pada Kelenjar getah bening \\
\hline G30 & $\begin{array}{l}\text { Nyeri menjalar dari pangkal kaki atau tangan } \\
\text { ke ujung jari }\end{array}$ \\
\hline G31 & Kaki membesar \\
\hline G32 & Tangan membesar \\
\hline G33 & Pada pria, scrotum bisa membesar \\
\hline G34 & Pembesaran payudara \\
\hline G35 & Muncul papula di kulit \\
\hline G36 & Gatal-gatal pada kulit \\
\hline G37 & Sakit Tenggorokan \\
\hline G38 & Suara serak \\
\hline G39 & Pilek/Flu \\
\hline G40 & Menggigil \\
\hline G41 & $\begin{array}{l}\text { bercak putih di tenggorokan atau mulut } \\
\text { bagian dalam }\end{array}$ \\
\hline G42 & Pembengkakan kelenjar parotis/ludah. \\
\hline
\end{tabular}

Tabel 3. Solusi Penyakit

\begin{tabular}{cl}
\hline Penyakit & \multicolumn{2}{c}{ Solusi } \\
\hline & $\begin{array}{l}\text { Pengobatan DBD yang terpenting } \\
\text { adalah menjaga agar kebutuhan } \\
\text { cairan didalam tubuh tercukupi }\end{array}$ \\
& dan mencegah tidak terjadinya \\
& dehidrasi. Hal ini bisa dilakukan \\
Demam & dengan pemberian cairan \\
Berdarah & Kristaloid secara Intravena \\
Dengue & (memberi cairan kealiran vena) \\
(DBD) & sesuai kebutuhan dan pemberian \\
& antipiretik (antidemam) untuk \\
& demamnya. Juga melakukan \\
& pemeriksaan darah lengkap \\
& secara berkala. \\
\hline
\end{tabular}




\begin{tabular}{|c|c|c|c|}
\hline Penyakit & Solusi & Penyakit & Solusi \\
\hline \multirow[b]{2}{*}{$\begin{array}{l}\text { Demam } \\
\text { Tifoid }\end{array}$} & $\begin{array}{l}\text { - Istirahat tirah baring dan } \\
\text { mengatur tahapan mobilisasi. - } \\
\text { Menjaga kecukupan asupan } \\
\text { cairan, yang dapat diberikan } \\
\text { secara oral (melalui mulut seperti } \\
\text { obat minum berupa table, kapsul } \\
\text { dan sirup) maupun parenteral }\end{array}$ & & $\begin{array}{l}\text { penyakit utama). } \\
\text { (Penatalaksanaan jika sudah } \\
\text { difasilitas kesehatan) Kontrol dan } \\
\text { monitor tanda vital (tekanan } \\
\text { darah, nadi, suhu, kesadaran), } \\
\text { kemudian dicatat dengan baik di } \\
\text { rekam medik pasien. }\end{array}$ \\
\hline & $\begin{array}{l}\text { (melaui cairan injeksi atau } \\
\text { suntikan). - Diet bergizi } \\
\text { seimbang, konsistensi lunak, } \\
\text { cukup kalori dan protein, rendah } \\
\text { serat. - Konsumsi obat antibiotik } \\
\text { dan antipiretik secara rutin dan } \\
\text { tuntas. - (Penatalaksanaan jika } \\
\text { sudah difasilitas kesehatan) } \\
\text { Kontrol dan monitor tanda vital } \\
\text { (tekanan darah, nadi, suhu, } \\
\text { kesadaran) didampingi ahli dan } \\
\text { kemudian akan dicatat didalam }\end{array}$ & $\begin{array}{l}\text { Varicella } \\
\text { (varisela) }\end{array}$ & $\begin{array}{l}\text { - Istirahat tirah baring dan } \\
\text { mengatur tahapan mobilisasi. - } \\
\text { Diet bergizi seimbang, cukup } \\
\text { kalori dan protein. - Konsumsi } \\
\text { obat antivirus secara rutin dan } \\
\text { tuntas. - (Penatalaksanaan jika } \\
\text { sudah difasilitas kesehatan) } \\
\text { Kontrol dan monitor tanda vital } \\
\text { (tekanan darah, nadi, suhu, } \\
\text { kesadaran), kemudian dicatat } \\
\text { dengan baik di rekam medik } \\
\text { pasien. }\end{array}$ \\
\hline Hepatitis & $\begin{array}{l}\text { rekam medik pasien. } \\
\text { - Istirahat tirah baring dan } \\
\text { mengatur tahapan mobilisasi. - } \\
\text { Menjaga kecukupan asupan } \\
\text { cairan, yang dapat diberikan } \\
\text { secara oral (melalui mulut seperti } \\
\text { obat minum berupa table, kapsul } \\
\text { dan sirup) maupun parenteral } \\
\text { (melaui cairan injeksi atau } \\
\text { suntikan). - Diet bergizi } \\
\text { seimbang, konsistensi lunak, } \\
\text { cukup kalori dan protein, rendah } \\
\text { serat. - Konsumsi obat antibiotik } \\
\text { dan antipiretik secara rutin dan } \\
\text { tuntas. }\end{array}$ & \multirow[t]{2}{*}{ Difteri } & $\begin{array}{l}\text { - Istirahat tirah baring dan } \\
\text { mengatur tahapan mobilisasi. - } \\
\text { Menjaga kecukupan asupan } \\
\text { cairan, yang dapat diberikan } \\
\text { secara oral maupun parenteral. - } \\
\text { Diet bergizi seimbang, } \\
\text { konsistensi lunak, cukup kalori } \\
\text { dan protein. - Konsumsi obat } \\
\text { antibiotik dan antipiretik } \\
\text { (antidemam)secara rutin dan } \\
\text { tuntas. - (Penatalaksanaan jika } \\
\text { sudah difasilitas kesehatan) } \\
\text { Kontrol dan monitor tanda vital } \\
\text { (tekanan darah, nadi, suhu, } \\
\text { kesadaran), kemudian dicatat }\end{array}$ \\
\hline \multirow{3}{*}{$\begin{array}{l}\text { Tuberkulosis } \\
\text { (TBC) }\end{array}$} & \multirow{3}{*}{$\begin{array}{l}\text { - Istirahat tirah baring. - Diet } \\
\text { bergizi seimbang, cukup kalori } \\
\text { dan protein, rendah serat. - } \\
\text { Konsumsi obat anti tuberkulosis } \\
\text { (OAT) dan antipiretik } \\
\text { (antidemam) secara rutin dan } \\
\text { tuntas. - (Penatalaksanaan jika } \\
\text { sudah difasilitas kesehatan) } \\
\text { Kontrol dan monitor tanda vital } \\
\text { (tekanan darah, nadi, suhu, } \\
\text { kesadaran)didampingi ahli dan } \\
\text { kemudian akan dicatat didalam } \\
\text { rekam medik pasien. }\end{array}$} & & $\begin{array}{l}\text { dengan baik di rekam medik } \\
\text { pasien. }\end{array}$ \\
\hline & & Morbili & \begin{tabular}{lrr} 
Pengobatan & Morbili yang \\
terpenting adalah melakukan & ah \\
isolasi untuk mencegah terjadinya \\
penularan, menjaga $r$ \\
kebutuhan cairan didalam tubuh \\
tercukupi dan mencegah tidak \\
terjadinya dehidrasi serta \\
menjaga kalori dalam tubuh. \\
Serta pemberian obat antipiretik, \\
\multicolumn{2}{l}{ obat antitusif dan sedatif. }
\end{tabular} \\
\hline & & & - Istirahat tirah baring/Bedrest. - \\
\hline $\begin{array}{c}\text { Filariasis } \\
\text { (Kaki Gajah) }\end{array}$ & $\begin{array}{l}\text { - Istirahat tirah baring dan } \\
\text { mengatur tahapan mobilisasi. - } \\
\text { Diet bergizi seimbang, cukup } \\
\text { kalori dan protein. - Konsumsi } \\
\text { obat obat anti filaria secara rutin } \\
\text { dan tuntas. - Bila perlu diberikan } \\
\text { pengobatan simptomatik (adalah } \\
\text { pengobatan dengan cara } \\
\text { memberikan obat sesuai gejala }\end{array}$ & $\begin{array}{c}\text { Parotitis } \\
\text { Epidemica }\end{array}$ & $\begin{array}{l}\text { Melakukan isolasi untuk } \\
\text { mencegah terjadinya penularan. - } \\
\text { Melakukan penanganan awal } \\
\text { dengan kompres dengan air } \\
\text { hangat dan konsumsi obat } \\
\text { analgetik, obat kkortikosteroid } \\
\text { selama 2-4 hari secara rutin dan } \\
\text { tuntas. - Diet bergizi seimbang, } \\
\text { konsistensi cair/lunak. }\end{array}$ \\
\hline
\end{tabular}




\begin{tabular}{|c|c|}
\hline Penyakit & Solusi \\
\hline Pertusis & $\begin{array}{l}\text { - Istirahat tirah baring. - Menjaga } \\
\text { kecukupan asupan cairan, yang } \\
\text { dapat diberikan secara oral } \\
\text { (melalui mulut seperti obat } \\
\text { minum berupa tablet, kapsul dan } \\
\text { sirup) maupun parenteral (melalui } \\
\text { cairan injeksi atau suntikan). - } \\
\text { Diet bergizi seimbang, } \\
\text { konsistensi lunak, cukup kalori } \\
\text { dan protein, rendah serat. - } \\
\text { Konsumsi obat antibiotik dan } \\
\text { obat expectoran dan mukolitik, } \\
\text { kodein, luminal secara rutin dan } \\
\text { tuntas. }\end{array}$ \\
\hline Leptospirosis & $\begin{array}{l}\text { - Istirahat tirah baring dan } \\
\text { mengatur tahapan mobilisasi. - } \\
\text { Menjaga kecukupan asupan } \\
\text { cairan, yang dapat diberikan } \\
\text { secara oral (melalui mulut seperti } \\
\text { obat minum berupa tablet, kapsul } \\
\text { dan sirup) maupun parenteral } \\
\text { (melalui cairan injeksi atau } \\
\text { suntikan). - Diet bergizi } \\
\text { seimbang, konsistensi lunak, } \\
\text { cukup kalori dan protein, cukup } \\
\text { serat. - Konsumsi obat antibiotik } \\
\text { berupa doksisiklin dan penicilin } \\
\text { secara rutin dan tuntas. - untuk } \\
\text { mengetahui hasil pastinya perlu } \\
\text { dilakukan tes urin, tes darah, } \\
\text { fungsi ginjal dan fungsi hati. }\end{array}$ \\
\hline
\end{tabular}

Tabel 4. Jenis Penyakit Penyakit Tropik Infeksi Beserta

\begin{tabular}{|c|c|c|c|}
\hline Kode & Penyakit & $\begin{array}{c}\text { Kode } \\
\text { Gejal } \\
\mathbf{a} \\
\end{array}$ & $\begin{array}{c}\text { CF } \\
\text { Pakar }\end{array}$ \\
\hline \multirow{10}{*}{ P01 } & \multirow{10}{*}{$\begin{array}{l}\text { Demam } \\
\text { Berdarah } \\
\text { Dengue } \\
\text { (DBD) }\end{array}$} & G1 & 1 \\
\hline & & G2 & 0,8 \\
\hline & & G3 & 0,4 \\
\hline & & G4 & 0,8 \\
\hline & & G5 & 0,6 \\
\hline & & G6 & 0,6 \\
\hline & & G7 & 1 \\
\hline & & G8 & 0,6 \\
\hline & & G9 & 0,6 \\
\hline & & G10 & 0,6 \\
\hline \multirow{6}{*}{ P02 } & \multirow{6}{*}{$\begin{array}{l}\text { Demam } \\
\text { Tifoid }\end{array}$} & G1 & 1 \\
\hline & & $\mathrm{G} 2$ & 0,8 \\
\hline & & G4 & 0,8 \\
\hline & & G11 & 1 \\
\hline & & G12 & 0,6 \\
\hline & & G13 & 0,8 \\
\hline
\end{tabular}

\begin{tabular}{|c|c|c|c|}
\hline Kode & Penyakit & $\begin{array}{c}\text { Kode } \\
\text { Gejal } \\
\mathbf{a} \\
\end{array}$ & $\begin{array}{c}\text { CF } \\
\text { Pakar }\end{array}$ \\
\hline & & G14 & 0,4 \\
\hline & & G15 & 0,6 \\
\hline & & G16 & 0,4 \\
\hline & & G17 & 0,4 \\
\hline \multirow{10}{*}{ P03 } & \multirow{10}{*}{ Hepatitis } & G1 & 1 \\
\hline & & G4 & 0,8 \\
\hline & & G5 & 0,6 \\
\hline & & G11 & 1 \\
\hline & & G13 & 0,8 \\
\hline & & G15 & 0,6 \\
\hline & & G18 & 1 \\
\hline & & G19 & 0,8 \\
\hline & & G20 & 1 \\
\hline & & G21 & 1 \\
\hline \multirow{9}{*}{ P04 } & \multirow{9}{*}{$\begin{array}{l}\text { Tuberkulosis } \\
\text { (TBC) }\end{array}$} & G1 & 1 \\
\hline & & G15 & 0,6 \\
\hline & & G22 & 1 \\
\hline & & G23 & 0,8 \\
\hline & & G24 & 0,8 \\
\hline & & G25 & 1 \\
\hline & & G26 & 1 \\
\hline & & G27 & 1 \\
\hline & & G29 & 1 \\
\hline \multirow{8}{*}{ P05 } & \multirow{8}{*}{$\begin{array}{c}\text { Filariasis } \\
\text { (Kaki } \\
\text { Gajah) }\end{array}$} & G1 & 1 \\
\hline & & $\mathrm{G} 28$ & 0,8 \\
\hline & & G29 & 1 \\
\hline & & G30 & 0,6 \\
\hline & & G31 & 1 \\
\hline & & G32 & 1 \\
\hline & & G33 & 0,8 \\
\hline & & G34 & 0,8 \\
\hline \multirow{8}{*}{ P06 } & \multirow{8}{*}{$\begin{array}{l}\text { Varicella } \\
\text { (varisela) }\end{array}$} & G1 & 1 \\
\hline & & G2 & 0,8 \\
\hline & & G4 & 0,8 \\
\hline & & G5 & 0,6 \\
\hline & & G6 & 0,6 \\
\hline & & G19 & 0,8 \\
\hline & & G35 & 1 \\
\hline & & G36 & 1 \\
\hline \multirow{8}{*}{ P07 } & \multirow{8}{*}{ Difteri } & G1 & 1 \\
\hline & & G19 & 0,8 \\
\hline & & G22 & 1 \\
\hline & & G29 & 1 \\
\hline & & G37 & 1 \\
\hline & & G38 & 1 \\
\hline & & G39 & 1 \\
\hline & & G40 & 0,6 \\
\hline
\end{tabular}




\begin{tabular}{|c|c|c|c|}
\hline Kode & Penyakit & $\begin{array}{c}\text { Kode } \\
\text { Gejal } \\
\mathbf{a}\end{array}$ & $\begin{array}{c}\text { CF } \\
\text { Pakar }\end{array}$ \\
\hline & & G41 & 1 \\
\hline \multirow{5}{*}{ P08 } & \multirow{5}{*}{ Morbili } & G01 & 1 \\
\hline & & G06 & 1 \\
\hline & & G22 & 0,6 \\
\hline & & G39 & 0,6 \\
\hline & & G37 & 0,6 \\
\hline \multirow{5}{*}{ P09 } & \multirow{5}{*}{$\begin{array}{l}\text { Parotitis } \\
\text { Epidemica }\end{array}$} & G01 & 1 \\
\hline & & G42 & 1 \\
\hline & & G04 & 0,8 \\
\hline & & G02 & 0,6 \\
\hline & & G15 & 0,6 \\
\hline \multirow{6}{*}{ P10 } & \multirow{6}{*}{ Pertusis } & G22 & 1 \\
\hline & & G39 & 0,8 \\
\hline & & G38 & 1 \\
\hline & & G01 & 1 \\
\hline & & G15 & 0,8 \\
\hline & & G11 & 0,6 \\
\hline \multirow{5}{*}{ P11 } & \multirow{5}{*}{ Leptospirosis } & G01 & 1 \\
\hline & & G04 & 0,8 \\
\hline & & G13 & 1 \\
\hline & & G18 & 1 \\
\hline & & G11 & 0,8 \\
\hline
\end{tabular}

Metode yang digunakan untuk mendapatkan tingkat keyakinan $(\mathrm{CF})$, menggunakan hasil wawancara dengan pakar. Berdasarkan informasi dari hasil wawancara dengan pakar. Nilai CF (Rule) didapat dari intrepretasi term dari pakar, yang diubah menjadi nilai $\mathrm{CF}$ tertentu sesuai tabel berikut ini.

Tabel 5. Nilai Ketidakpastian

\begin{tabular}{cc}
\hline Uncertain Term & CF \\
\hline Pasti Tidak & -1.0 \\
\hline Hampir pasti tidak & -0.8 \\
\hline Kemungkinan besar tidak & -0.6 \\
\hline Mungkin tidak & -0.4 \\
\hline Tidak tahu & -0.2 to 0.2 \\
\hline Mungkin & 0.4 \\
\hline Kemungkinan Besar & 0.6 \\
\hline Hampir pasti & 0.8 \\
\hline Pasti & 1.0
\end{tabular}

Setelah diketahui data penyakit dan gejala penyakit maka kemudian melakukan proses inferensi. Analisis proses inferensi dimana data gejala yang telah dipilih oleh user akan diproses dengan menggunakan metode Certainty Factor. Cara perhitungannya dimana data gejala yang telah dipilih sebelumnya akan dihitung nilai CF dari satu atau beberapa jenis penyakit yang dipengaruhi oleh gejala tersebut.

Sebagai contoh kasus perhitungan secara manual analisis kebutuhan input adalah termasuk kedalam jenis penyakit tropik infeksi. Seorang user mengalami gejala penyakit tropik infeksi yaitu sebagai berikut di bawah ini:

Tabel 6. Gejala Yang Dialami

\begin{tabular}{clcc}
\hline $\begin{array}{c}\text { Kode } \\
\text { Gejala }\end{array}$ & \multicolumn{1}{c}{ Gejala } & $\begin{array}{c}\text { CF } \\
\text { User }\end{array}$ & Keterangan \\
\hline G01 & Demam & 0,8 & Hampir pasti \\
\hline G03 & $\begin{array}{l}\text { Nyeri Bagian } \\
\text { Mata }\end{array}$ & 0,8 & Hampir pasti \\
\hline G05 & Nyeri Sendi & 0,8 & Hampir pasti \\
\hline G06 & $\begin{array}{l}\text { Ruam (Bintik) } \\
\text { Kemerahan }\end{array}$ & 0,6 & $\begin{array}{c}\text { Kemungkinan } \\
\text { Besar }\end{array}$ \\
\hline G10 & $\begin{array}{l}\text { Jumlah volume } \\
\text { urine menurun }\end{array}$ & 0,8 & Hampir pasti \\
\hline
\end{tabular}

Tabel 7. Rule Gejala Yang Dialami

P01 - Demam Berdarah Dengue (DBD)

\begin{tabular}{|c|c|c|c|c|}
\hline $\begin{array}{c}\text { Kode } \\
\text { Gejala }\end{array}$ & Gejala & $\begin{array}{c}\text { CF } \\
\text { Pakar }\end{array}$ & $\begin{array}{c}\text { CF } \\
\text { User }\end{array}$ & $\begin{array}{c}\text { CF } \\
\text { Pakar* } \\
\text { CF } \\
\text { User } \\
\end{array}$ \\
\hline G01 & Demam & 1 & 0,8 & 0,8 \\
\hline G03 & $\begin{array}{l}\text { Nyeri Bagian } \\
\text { Mata }\end{array}$ & 0,4 & 0,8 & 0,32 \\
\hline G05 & Nyeri Sendi & 0,6 & 0,8 & 0,48 \\
\hline G06 & $\begin{array}{l}\text { Ruam (Bintik) } \\
\text { Kemerahan }\end{array}$ & 0,6 & 0,6 & 0,36 \\
\hline G10 & $\begin{array}{l}\text { Jumlah volume } \\
\text { urine menurun }\end{array}$ & 0,6 & 0,8 & 0,48 \\
\hline \multicolumn{5}{|c|}{ P02 - Demam Tifoid } \\
\hline $\begin{array}{c}\text { Kode } \\
\text { Gejala }\end{array}$ & Gejala & $\begin{array}{c}\text { CF } \\
\text { Pakar }\end{array}$ & $\begin{array}{c}\text { CF } \\
\text { User }\end{array}$ & $\begin{array}{c}\text { CF } \\
\text { Pakar* } \\
\text { CF } \\
\text { User }\end{array}$ \\
\hline G01 & Demam & 1 & 0,8 & 0,8 \\
\hline \multicolumn{5}{|c|}{ P03 - Hepatitis } \\
\hline $\begin{array}{c}\text { Kode } \\
\text { Gejala }\end{array}$ & Gejala & $\begin{array}{c}\text { CF } \\
\text { Pakar }\end{array}$ & $\begin{array}{c}\text { CF } \\
\text { User }\end{array}$ & $\begin{array}{c}\text { CF } \\
\text { Pakar* } \\
\text { CF } \\
\text { User }\end{array}$ \\
\hline G01 & Demam & 1 & 0,8 & 0,8 \\
\hline G05 & Nyeri Sendi & 0,6 & 0,8 & 0,48 \\
\hline \multicolumn{5}{|c|}{ P04 - Tuberkulosis (TBC) } \\
\hline $\begin{array}{c}\text { Kode } \\
\text { Gejala }\end{array}$ & Gejala & $\begin{array}{c}\text { CF } \\
\text { Pakar }\end{array}$ & $\begin{array}{c}\text { CF } \\
\text { User }\end{array}$ & $\begin{array}{c}\text { CF } \\
\text { Pakar* } \\
\text { CF } \\
\text { User }\end{array}$ \\
\hline G01 & Demam & 1 & 0,8 & 0,8 \\
\hline \multicolumn{5}{|c|}{ P05 - Filariasis (Kaki Gajah) } \\
\hline $\begin{array}{c}\text { Kode } \\
\text { Gejala }\end{array}$ & Gejala & $\begin{array}{c}\text { CF } \\
\text { Pakar }\end{array}$ & $\begin{array}{c}\text { CF } \\
\text { User }\end{array}$ & $\begin{array}{c}\text { CF } \\
\text { Pakar* } \\
\text { CF } \\
\text { User }\end{array}$ \\
\hline
\end{tabular}




\begin{tabular}{|c|c|c|c|c|c|}
\hline G01 & Demam & 1 & 0,8 & 0,8 & \multirow{7}{*}{$\begin{array}{l}\text { 7. Perhitungan CF untuk penyakit P07 dengan } 1 \text { gejala : } \\
\text { Karena gejalanya hanya } 1 \text { maka tidak perlu } \\
\text { dihitung kombinasi CF. maka nilai akhir CF untuk } \\
\text { penyakit P07 adalah sebesar } 0,8 \text { atau } 80 \% \text {. } \\
\text { Hasil Pembahasan : Berdasarkan perhitungan dengan } \\
\text { metode Certainty Factor diatas diperoleh nilai kepastian } \\
\text { (nilai CF) tertinggi pada Penyakit P01. Maka dapat } \\
\text { disinpulkan pasien mengalami penyakit P01 (Penyakit } \\
\text { DBD) dengan nilai CF =0,9765 atau 97,65\%. tingkat } \\
\text { kepastian. Pengobatan DBD yang terpenting adalah } \\
\text { menjaga agar kebutuhan cairan didalam tubuh tercukupi } \\
\text { dan mencegah tidak terjadinya dehidrasi. Hal ini bisa } \\
\text { dilakukan dengan pemberian cairan Kristaloid secara } \\
\text { Intravena (memberi cairan kealiran vena) sesuai }\end{array}$} \\
\hline \multicolumn{5}{|c|}{ P06 - Varicella (varisela) } & \\
\hline $\begin{array}{c}\text { Kode } \\
\text { Gejala }\end{array}$ & Gejala & $\begin{array}{c}\text { CF } \\
\text { Pakar }\end{array}$ & $\begin{array}{c}\text { CF } \\
\text { User }\end{array}$ & $\begin{array}{c}\text { CF } \\
\text { Pakar* } \\
\text { CF } \\
\text { User }\end{array}$ & \\
\hline G01 & Demam & 1 & 0,8 & 0,8 & \\
\hline G06 & $\begin{array}{l}\text { Ruam } \\
\text { (Bintik) } \\
\text { Kemerahan }\end{array}$ & 0,6 & 0,6 & 0,36 & \\
\hline \multicolumn{5}{|c|}{ P07 - Difteri } & \\
\hline $\begin{array}{c}\text { Kode } \\
\text { Gejala }\end{array}$ & Gejala & $\begin{array}{c}\text { CF } \\
\text { Pakar }\end{array}$ & $\begin{array}{c}\text { CF } \\
\text { User }\end{array}$ & $\begin{array}{c}\text { CF } \\
\text { Pakar* } \\
\text { CF } \\
\text { User }\end{array}$ & \\
\hline G01 & Demam & 1 & 0,8 & 0,8 & kebutuhan dan pemberian antipiretik (antidemam) untuk \\
\hline
\end{tabular}
dibawah ini:

1. Kombinasi $\mathrm{CF}$ untuk penyakit $\mathrm{P} 01$ dengan 5 gejala :

$$
\begin{aligned}
\mathrm{CF}(\mathrm{R} 1, \mathrm{R} 2) & =\mathrm{CF}(\mathrm{R} 1)+\mathrm{CF}(\mathrm{R} 2) *(1-\mathrm{CF}(\mathrm{R} 1)) \\
=0.864 & =0.80+(0.32 *(1-0,80)) \\
\mathrm{CF}(\mathrm{old} 1, \mathrm{R} 3) & =\mathrm{CF}(\mathrm{old} 1)+\mathrm{CF}(\mathrm{R} 3) *(1-\mathrm{CF}(\mathrm{old} 1)) \\
& =0.864+(0.48 *(1-0.864)) \\
& =0,9293 \\
\mathrm{CF}(\mathrm{old} 2, \mathrm{R} 4) & =\mathrm{CF}(\mathrm{old} 2)+\mathrm{CF}(\mathrm{R} 4) *(1-\mathrm{CF}(\mathrm{old} 2)) \\
& =0,9293+(0,36 *(1-0,9293)) \\
& =0,9547 \\
\mathrm{CF}(\mathrm{old} 3, \mathrm{R} 5) & =\mathrm{CF}(\mathrm{old} 3)+\mathrm{CF}(\mathrm{R} 4) *(1-\mathrm{CF}(\mathrm{old} 3)) \\
& =0,9547+(0,48 *(1-0,9547)) \\
& =0,9765
\end{aligned}
$$

Nilai akhir CF untuk penyakit P01 adalah sebesar 0,9765 atau $97,65 \%$.

2. Perhitungan $\mathrm{CF}$ untuk penyakit $\mathrm{P} 02$ dengan 1 gejala :

Karena gejalanya hanya 1 maka tidak perlu dihitung kombinasi CF. maka Nilai akhir $\mathrm{CF}$ untuk penyakit $\mathrm{P} 02$ adalah sebesar 0,8 atau $80 \%$.

3. Perhitungan $\mathrm{CF}$ untuk penyakit $\mathrm{P} 03$ dengan 2 gejala :

$$
\begin{aligned}
\mathrm{CF}(\mathrm{R} 1, \mathrm{R} 2) & =\mathrm{CF}(\mathrm{R} 1)+\mathrm{CF}(\mathrm{R} 2) *(1-\mathrm{CF}(\mathrm{R} 1)) \\
& =0.80+(0.48 *(1-0,80)) \\
& =0,8960
\end{aligned}
$$

Nilai akhir CF untuk penyakit $\mathrm{P} 03$ adalah sebesar 0,8960 atau $89,60 \%$.

4. Perhitungan $\mathrm{CF}$ untuk penyakit P04 dengan 1 gejala :

Karena gejalanya hanya 1 maka tidak perlu dihitung kombinasi CF. maka Nilai akhir CF untuk penyakit P04 adalah sebesar 0,8 atau 80\%.

5. Perhitungan $\mathrm{CF}$ untuk penyakit P05 dengan 1 gejala :

Karena gejalanya hanya 1 maka tidak perlu dihitung kombinasi CF. maka Nilai akhir CF untuk penyakit $\mathrm{P} 05$ adalah sebesar 0,8 atau $80 \%$.

6. Perhitungan $\mathrm{CF}$ untuk penyakit $\mathrm{P} 06$ dengan 2 gejala :

$$
\begin{aligned}
\mathrm{CF}(\mathrm{R} 1, \mathrm{R} 2) & =\mathrm{CF}(\mathrm{R} 1)+\mathrm{CF}(\mathrm{R} 2) *(1-\mathrm{CF}(\mathrm{R} 1)) \\
& =0.80+(0.36 *(1-0,80)) \\
& =0,8720
\end{aligned}
$$

IV. IMPLEMENTASI SISTEM

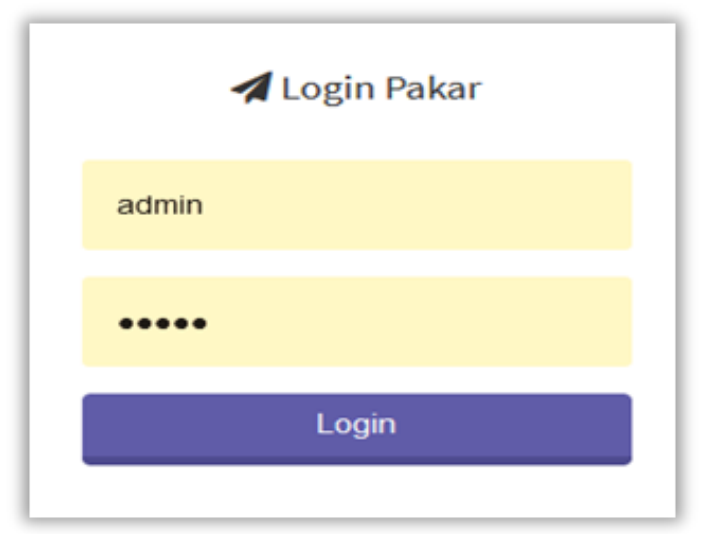

Gambar 2. Form Login

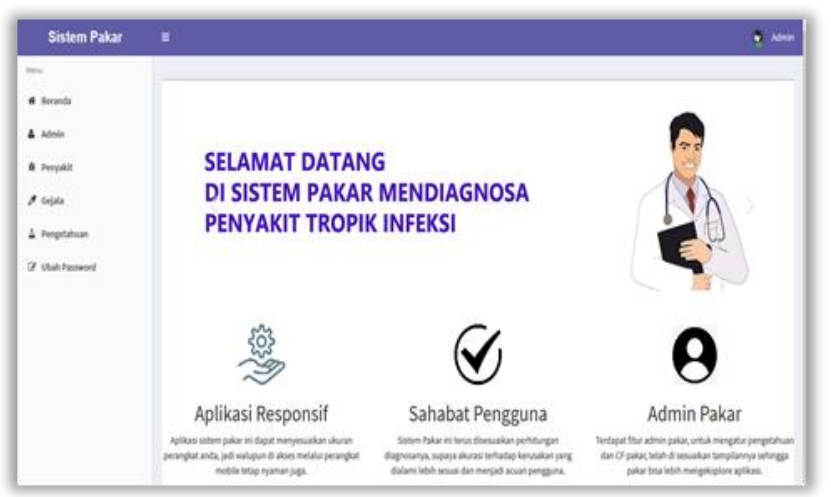

Gambar 3. Tampilan Form Beranda 


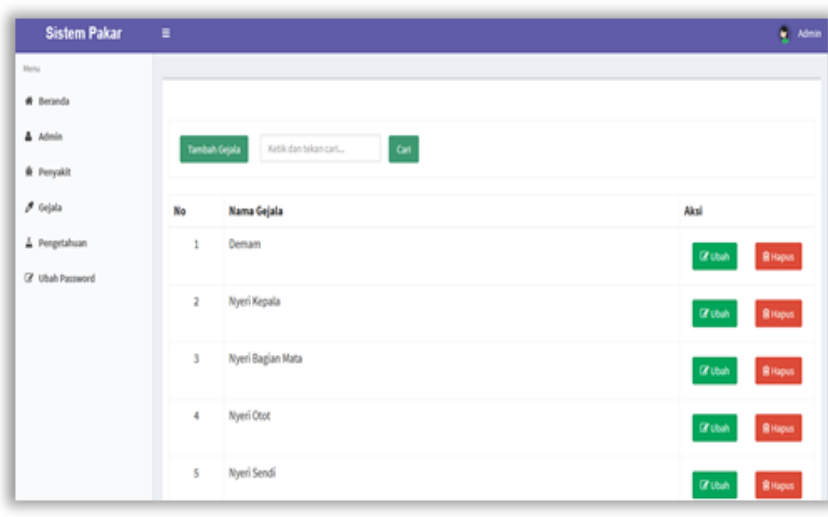

Gambar 4. Tampilan Form Gejala

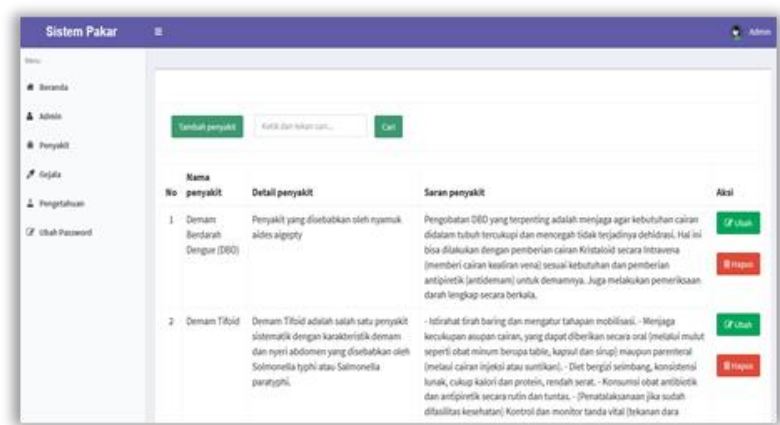

Gambar 5. Tampilan Form Input Data Penyakit

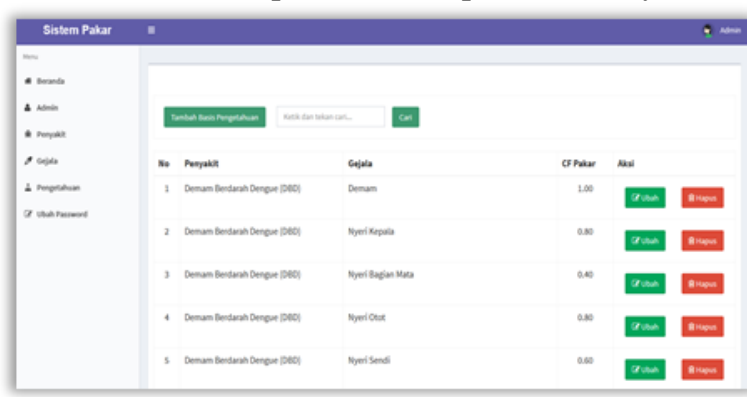

Gambar 6. Tampilan Form Basis Pengetahuan

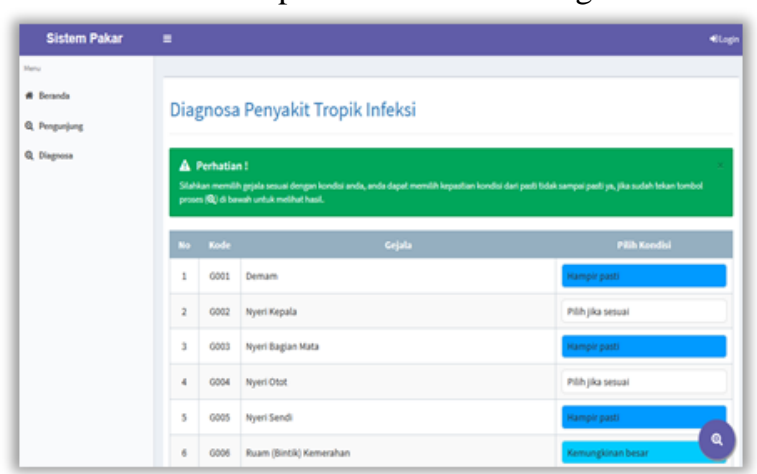

Gambar 7. Tampilan Form Diagnosa
Hasil Diagnosa Penyakit Tropik Infeksi

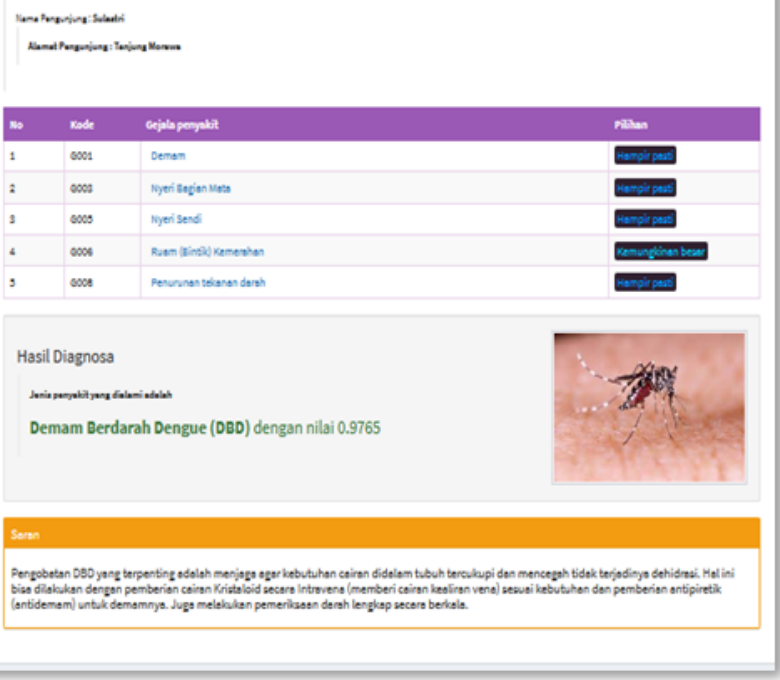

Gambar 8. Hasil Laporan Diagnosa

\section{KESIMPULAN}

Berdasarkan penelitian serta uraian diatas, maka didapatkan kesimpulan sebagai berikut:

1. Aplikasi sistem pakar mendiagnosa penyakit tropik infeksi berbasis web yang dibangun mampu serta cukup akurat dalam mendiagnosa penyakit tropik infeksi.

2. Metode Certainty Factor yang diterapkan dalam aplikasi mampu menyelesaikan perhitungan dengan output yang dikeluarkan berupa jenis penyakit beserta solusi.

\section{REFERENSI}

[1] Agustina, D., Mustafidah, H., \& Purbowati, M. R. (2016). Sistem Pakar Diagnosa Penyakit Kulit Akibat Infeksi Jamur ( Expert System to Diagnose of Skin Disease Due to Fungal Infections ). Juita Issn: 2086-9398, IV(2), 67-77.

[2] Aulady, F., Gunawan, A., \& Ryansyah, M. (2019). Penerapan Algoritma Certainty Factor Untuk Sistem Pakar Diagnosis Urtikaria Pada Wanita Dewasa. Swabumi, 7(1), 90-98. https://doi.org/10.31294/swabumi.v7i1.6173

[3] Azmi, Z., \& Yasin, V. (2017). Pengantar Sistem Pakar dan Metode (Introduction of Expert System and Methods). Mitra Wacana Media.

[4] Dinas Kesehatan Sumatera Utara. (2019). Profil Kesehatan Provinsi Sumatera Utara 2019. Jurnal Ilmiah Smart, III(2), 68-80.

[5] DosenPendidikan. (2021). Simbol Flowchart. Dosen Pendidikan Website. https://www.dosenpendidikan.co.id/simbolflowchart/

[6] Fertian, W. (2016). Pengertian Database Server. Binus Website. https://studentactivity.binus.ac.id/himsisfo/2016/07/pengertiandatabase-server/ 
[7] Galih Pradana, A., \& Nita, S. (2019). Rancang Bangun Game Edukasi “ AMUDRA " Alat Musik Daerah Berbasis Android Afista Galih Pradana Sekreningsih Nita. Seminar Nasional Teknologi Informasi Dan Komunikasi, 2(1), 77-80.

[8] Kemenkes RI. (2019). Profil Kesehatan Indonesia Tahun 2019. In Kementrian Kesehatan Repoblik Indonesia (Vol. 42, Issue 4).

[9] Kemenkes RI. (2018). Kesiapsiagaan Menghadapi Peningkatan Kejadian Demam Berdarah Dengue Tahun 2019. Kementrian Kesehatan Republik Indonesia. http://p2p.kemkes.go.id/kesiapsiagaanmenghadapi-peningkatan-kejadian-demamberdarah-dengue-tahun-2019/

[10] Krishna Panolih. (2021). Penyakit Tropis Terabaikan di masa Pendemi. Kompas.Id. https://kompaspedia.kompas.id/baca/paparantopik/penyakit-tropis-terabaikan-di-masa-pandemi 